\title{
Empowerment of Village-Owned Enterprises (Comparative Study on Empowerment of Village-Owned Enterprises in Padang Jaya Village and Modang Village, Kuaro District, Paser Regency)
}

\author{
Hendra Putra*, Muhammad Riduansyah Syafari, Ahmad Yunani, Andi Tenri Sompa
}

Masters in Development Administration, Postgraduate Program, Lambung Mangkurat University, J1. Brigjen H. Hasan Basri, Pangeran, Kec. Banjarmasin Utara, Kota Banjarmasin, Kalimantan Selatan 70123, Indonesia

DOI: $10.36348 /$ sjef.2020.v04i11.003

| Received: 29.10.2020 | Accepted: 11.11.2020 | Published: 17.11.2020

*Corresponding author: Hendra Putra

\section{Abstract}

This study aims to determine the comparison of community empowerment and explain the obstacles through the management of Village-Owned Enterprises (BUMdesa) in Padang Jaya Village and Modang Village, Kuaro District, Paser Regency. A qualitative approach was used to collect and analyze data in the form of words and human actions regarding the comparison of BUMDesa empowerment in Padang Jaya Village and Modang Village, Kuaro District, Paser Regency. Research informants consisted of the Community Empowerment Service and Village Government of Paser Regency, Kuaro District, Paser Regency, Village Head/Village Apparatus, Kuaro District, Paser Regency, BUMDesa Management, Kuaro District, Paser Regency, and BUMDesa Consumer/Participation Communities. The data sources used are primary data and secondary data. Primary data is data obtained directly from informants at the research location, namely those located in Kuaro District, Paser Regency, East Kalimantan Province. Secondary data is data obtained from various supporting scientific libraries and from existing documents obtained from agencies or institutions related to this research. The data collection technique was carried out in three steps, namely: observation, interviews, and documentation. The results showed that the empowerment of BUMDesa in Padang Jaya Village and Modang Village, Kuaro District, Paser Regency was maximal where BUMDesa in Padang Jaya Village was superior to BUMDesa in Modang Village. Some of the obstacles encountered include limited human resources both in terms of quantity and quality, in addition to that there are bureaucratic obstacles that have an impact on the capital of BUMDesa.

Keywords: Empowerment, management, BUMDes.

Copyright (9) 2020 The Author(s): This is an open-access article distributed under the terms of the Creative Commons Attribution 4.0 International License (CC BY-NC 4.0) which permits unrestricted use, distribution, and reproduction in any medium for non-commercial use provided the original author and source are credited.

\section{INTRODUCTION}

The issuance of Law Number 6 of 2014 concerning Villages, makes the village a hybrid society between self-governing communities and local selfgovernment. This of course makes the Village as a Village government requires a new management system to realize its role in accordance with the mandate of Village autonomy. Village-owned enterprises (BUMDesa) have a strategic position in supporting the realization of Village independence. BUMDesa can become the backbone of the Village administration which in the end can realize Village independence and increase community welfare.

One of the government's strategies to facilitate the village in increasing the village's original income is the issuance of the Regulation of the Minister of Villages, Disadvantaged Areas and Transmigration
Number 4 of 2015 concerning the Establishment, Management and Management, and Disbanding of Village-Owned Enterprises which states that the Village government can establish Village-Owned Enterprises BUMDesa). Based on the Regional Regulation of Paser Regency Number 03 of 2018 concerning the Establishment, Management and Management and Dissolution of Village-Owned Enterprises, BUM Desa is a business entity which is wholly or most of its capital is owned by the Village through direct participation which comes from separated Village assets to manage assets, services, and other efforts to improve the welfare of the Village community. The establishment of Village-Owned Enterprises aims to drive local economic development at the Village level. The local economic development of this Village is based on the needs, potential, capacity of the Village, and the participation of capital from the Village government in the form of Village financing and wealth 
with the ultimate goal of increasing the economic level of the Village community.

The role played by empowerment is essentially to strengthen competitiveness and resource capacity, including the ability of individuals, groups, organizations and institutions. Sumodiningrat [1] suggests indicators of success used to measure the implementation of community empowerment programs, namely the reduction in the number of poor people and increased community capacity and income distribution. Sumardjo [2] states that the characteristics of community members are competitive and capable of human resources, namely 1) being able to understand themselves and their potential, and being able to plan (anticipating conditions of change in the future), 2) being able to direct themselves, 3 ) having the power to negotiate, and 4) have adequate bargaining power in conducting mutually beneficial cooperation, and are responsible for their actions.

Community empowerment aims to empower several community groups in a socio-economic way so that they are more independent and can fulfill their basic life needs and are able to participate in community development. Making communities empowered and independent can be done by strengthening the capacity of three aspects, namely strengthening individual capacity, institutional capacity (organizational and behavioral values), and networking capacity. The process of community empowerment starts from the awareness process to strengthening capacity or empowerment Wikirannoio and Riant, 2007. Mardikanto and Soebiato [3] describe the capacity building process as follows:

1. First, strengthening individual capacities. Strengthening capacity is all efforts to improve or develop the quality of personal characteristics to be more effective and efficient, both within the entity and globally.

2. Second, institutional capacity building. This capacity development emphasizes the development of organizational / institutional quality.

3. Third, strengthening the capacity of the networking system. The development of network capacity is in line with global developments, where the world knows almost no boundaries.

Capacity building is usually carried out in groups and organized, involving several strategies such as education and training, productive economy, social care, awareness and attitude and behavior change, advocacy for client rights, socialization, campaigns, demonstrations, collaborations, contests, or changes to public policies to be more responsive to the needs of the target group [4].

Paser Regency is divided into 10 Districts, 5 Kelurahan and 139 Villages. Among the many villages in Paser Regency, there are several villages that already have Village-Owned Enterprises (BUMDesa) which are well managed and run. In total there are 88 villages that have BUMDesa that are already good or in the stages of formation, capital participation and business unit development. In Kuaro sub-district, there are 12 villages that have BUMDesa, some of which are already good or currently in the stages of formation, capital participation and business unit development.

Based on the explanation above, the researcher is interested in conducting research with the title empowerment of village-owned enterprises (a comparative study of the empowerment of BUMDesa in Padang Jaya Village and Modang Village, Kuaro District, Paser Regency). The reason for taking BUMDesa from Modang Village is because BUMDesa in Modang Village looks active and runs with many sectors in the community. In addition, the researcher saw that the BUMDesa Padang Jaya that the researcher chose was one of the BUMDesa that became a pilot in Kuaro District, Paser Regency, so the researchers saw that the two BUMDes were worthy of being studied for their empowerment and management.

\section{RESEARCH METHODS}

This study used a qualitative descriptive approach with the aim of knowing the comparison of community empowerment and explaining the constraints of community empowerment through the management of BUMDesa in Padang Jaya Village and Modang Village, Kuaro District, Paser Regency. This research activity was carried out in the BUMDesa group in Kuaro District, namely BUMDesa Amanah in Padang Jaya Village and BUMDesa Sama Umpu in Modang Village.

The research subject was aimed at exploring data and information related to community empowerment and the obstacles faced in the management of BUMDesa in Padang Jaya Village and Modang Village, Kuaro District, Paser Regency. The informants in this study were the Department of Community Empowerment and Village Government of Paser Regency, Kuaro District, Paser Regency, Village Head / Village Apparatus, Kuaro District, Paser Regency, BUMDesa Management, Kuaro District, Paser Regency, and BUMDesa Consumer / Participation Communities. There are three steps of data collection, namely: 1) Observation by observing the BUMDesa group to be studied, 2) Interviewing by conducting direct questions and answers to informants to get the information needed, and 3) Documentation is done by collecting existing data sources in the form of a document to check its legality.

The data analysis technique used in this study was data analysis from Huberman and Millies which was divided into three stages, namely data codification, data presentation, and conclusion / verification. The data adjustment stage is the data coding stage by 
rewriting the field annotations. Then use tags to select and organize important and irrelevant information. Presentation of data requires steps that aim to classify and organize the data into groups. Then at the stage of drawing conclusions the researcher provides a brief summary of the existing data findings.

The data triangulation stage is used as a data validation test technique by using something outside the data for examination purposes or as a source of comparison to existing data. Wiersma argues that testing through triangulation can provide the truth and as confirmation of data obtained from various sources. This study used data triangulation and source triangulation techniques [5].

\section{RESEARCH RESULTS AND DISCUSSION}

Based on the data obtained by researchers, the assessment of the classification of BUMDes development in Paser Regency can be seen in Table-1 as follows:

Table-1: Recapitulation of BUMDes Development Classification Assessment in Paser Regency

\begin{tabular}{|l|l|l|l|l|l|}
\hline $\begin{array}{l}\text { District } \\
\text { Name }\end{array}$ & Village Name & BUMDes Name & $\begin{array}{l}\text { Impact of BUMDes } \\
\text { on Society }\end{array}$ & $\begin{array}{l}\text { Total Overall } \\
\text { Score }\end{array}$ & $\begin{array}{l}\text { Rating } \\
\text { Classification }\end{array}$ \\
\hline Kuaro & Kendarom & Kendarom Jaya & 2.50 & 28.54 & BASIC \\
\hline Kuaro & Kertabumi & Usaha Jaya Makmur & 2.50 & 28.13 & BASIC \\
\hline Kuaro & Padang Jaya & Amanah & 9.17 & 80.63 & DEVELOP \\
\hline Kuaro & Klempang Sari & Sari Risqi & 6.67 & 45.21 & BASIC \\
\hline Kuaro & Rangan & Penyembolum & 5.83 & 55.83 & GROW \\
\hline Kuaro & Sandeley & Empun Takase & 4.17 & 37.29 & BASIC \\
\hline Kuaro & Modang & Sama Umpu & 5.00 & 45.63 & BASIC \\
\hline Kuaro & Pasir Mayang & ulo Taka & 2.50 & 27.08 & BASIC \\
\hline Kuaro & Lolo & Lolo Semelir & 2.50 & 23.54 & BASIC \\
\hline Kuaro & Keluang Paser Jaya & Mitra Mandiri Jaya & 3.33 & 38.33 & BASIC \\
\hline Kuaro & Pondong Baru & Pondong Mandiri & 2.50 & 27.08 & BASIC \\
\hline Kuaro & Harapan Baru & Harapan Bolum & 2.50 & 27.08 & BASIC \\
\hline
\end{tabular}

Source: Paser Regency DPMD Office, 2020

Based on Table-1, it can be observed that BUMDesa from Padang Jaya Village, Kuaro subdistrict is the only village that received a "Developing" assessment from the Regional Government of Paser Regency by getting a total value classification of 80.63 . Meanwhile, Modang village received a "basic" rating with a total value classification of 45.63. This assessment shows that the BUMDesa Padang Jaya called BUMDesa Amanah is a pilot BUMDesa that deserves to be used as a reference by the surrounding BUMDes in Paser Regency, East Kalimantan Province. Aspects of assessment of BUMDesa in Kuaro subdistrict, Paser Regency are based on 6 aspects, namely institutional aspects, rules and legality, BUMDesa business fields, administration, reporting and accountability, capital and assets and the impact of BUMDesa on village communities. Here, the researcher focuses on the aspects of BUMDesa's impact on rural communities including the regional, economic and social development side because it is very closely related to human resources.

\section{The process of community empowerment is through BUMDes Amanah Padang Jaya Village and BUMDesa Sama Umpu, Modang Village, Kuaro District}

Community empowerment is an effort to develop independence and community welfare by increasing knowledge, attitudes, skills, behavior, abilities, awareness, and utilizing resources through the establishment of policies, programs, activities and assistance in accordance with the essence of problems and priority needs of the village community. Padang Jaya and Modang Village Governments established BUMDesa Amanah and BUMDesa Sama Umpu to increase community income by utilizing the existing potential in the community and in accordance with the community's needs. Awareness is the initial stage in community empowerment. Awareness was carried out by BUMDesa Amanah and BUMDesa Sama Umpu as well as the local village government by providing socialization to the community about the importance of maximizing the potential of the village. In addition, this awareness stage also uses the Mezzo approach, which is an approach that is carried out using groups as an intervention that is carried out slowly with a series of training activities in order to provide enlightenment and motivation to the local community to continue to develop potential expertise in developing good types of business. already running and new types of business in order to achieve a prosperous community economy.

The author concludes that with the awareness carried out by BUMDesa Amanah and BUMDesa Sama, the community is more active in developing potential both in terms of human resources and from various types of businesses that will be further developed.

\section{Strengthening Individual Capacity}

Strengthening individual capacities includes strengthening personal capacities, strengthening capacities in the world of work, and strengthening professional capacities. 


\section{a. Strengthening Personality Capacity}

Based on the research findings, the process of strengthening the personality capacity through strengthening the capacity of special individuals in the Amanah BUMDesa is not overly emphasized because members of the Amanah BUMDesa already have more specific knowledge and skills to advance the Amanah BUMDesa through the development of institutional capacity and capacity to strengthen networks. Whereas at BUMDesa Sama Umpu not all Capacity Building is applied, but the process of strengthening individual and institutional capacities is prioritized because it is still in the basic process. This is because BUMDesa Sama Umpu is more concerned with fostering the personalities of its members in developing elements of knowledge and skills for BUMDes members in developing business units that are useful for empowering communities in their region.

\section{b. Strengthening Institutional Capacity}

Strengthening institutional capacity in rural community empowerment is seen from the clarity of the vision, mission, and organizational culture, as well as clarity of organizational structure, competencies and strategies to achieve organizational goals. Based on observations and documentation, the vision and mission of empowering BUMDesa Amanah and BUMDesa Sama Umpu is clearly and firmly stated. During the implementation of empowerment, the BUMDesa Amanah and BUMDesa Sama Umpu have an inherent organizational culture, namely local culture. A culture that is heavily influenced by Islamic values, such as mutual cooperation, kinship, honesty and discipline. Village deliberations in planning activities based on deliberation to reach consensus and majority votes. The empowerment of the Amanah BUMDesa is quite good because of the balanced division of tasks for the secretary, treasurer, and staff.

Referring to the application of Capacity Building theory, the strengthening of institutional capacity carried out and implemented by the two BUMDesa in their respective regions has been very good. This can be seen from the implementation which refers to the mastery of knowledge based on: 1) clarity of the implementation of the vision, mission and organizational culture; 2) clarity of the organizational structure, competencies and strategies for achieving organizational goals, and the development of the number and quality of organizational resources.

\section{c. Strengthening Network System Capacity or Networking}

Strengthening the capacity of the network system/networking is carried out in developing interactions between organizations within the same system and on developing organizational networks outside the system. Development of interaction between organizations in the same system, consisting of: 1) the perpetrator organization; 2) government organizations/public institutions; 3) business institution organization; 4) community organizations; 6) nongovernmental organizations/NGO; 7) interest organizations / hobbies.

The BUMDesa Amanah empowerment organization tries to build communication with outsiders with friendships in the social media group, one of which is to increase creativity, both thinking and acting in improving BUMDesa Amanah's human resources. In addition, the government organizations involved in empowering BUMDesa Amanah and BUMDesa Sama Umpu are government organizations related to the BUMDesa empowerment program outlined in the Regent's Decree. The organizations directly involved in the Regent's Decree are the DPMD (Community and Village Empowerment Service), the District, and the organizations under the Village Government. In addition, the creativity of BUM Desa Amanah through the Chairman is able to build networks to organizations with outside parties.

Strengthening and developing community organizational networks for empowering BUMDesa Amanah and BUMDesa Sama Umpu looks optimal. Likewise, the strengthening and development of interest networks/hobbies, empowerment of BUMDesa Amanah and BUMDesa Sama Umpu is very good, especially in building networks with outside parties.

Interactions with organizations outside the system consist of socio-political organizations, government organizations/public institutions, economic organizations. Strengthening and developing networks to socio-political organizations, in this case the DPRD, which accommodates political organizations in Paser Regency. The involvement of the DPRD in empowering BUMDesa Amanah and BUMDesa Sama Umpu is one of which is the making of the Regional Regulation on BUMDesa Number 3 of 2018. Strengthening networks with government organizations that are directly related to the empowerment of BUMDesa Amanah and BUMDesa Sama Umpu, namely DPMD as a supervisor with the licensing agency for well-established government organization relations. The development and strengthening of economic organization networks is more about getting a business development network and product marketing. Without such a marketing network, it is difficult for MSME beginners to be able to market their products and maintain their business continuity, one of the culinary delights that has been successfully fostered by BUMDesa Amanah.

\section{CONCLUSION}

Based on the above explanation, it can be concluded that the level of success of the BUMDesa program in community economic empowerment can be seen from the level of community participation, income level of BUMDesa members and the level of community welfare. The implementation of the BUMDesa program in Modang Village and Padang 
Jaya Village in empowering business entities received an explanation regarding the strengthening of Individual Capacity, namely in 3 aspects including Personality capacity development where BUMDesa Padang Jaya got a superior personality capacity than BUMDesa Modang, then Capacity Development in the world of work where BUMDesa Amanah in Padang Jaya Village has received a "Developing" rating compared to BUMDesa Modang which is still in a "Basic" assessment. Professional capacity building, entity (institutional) capacity building and system capacity building (networking) are both implemented by the two BUMDesa in Kuaro District.

The obstacle faced by Padang Jaya and Modang BUMDes in managing the development potential of BUMDesa is the limited human resources (HR) both in quantity and quality. Efforts are being made to overcome this problem, namely BUMDesa always conducts training so that the skills of the management and villagers are increasing. Another obstacle is the problem of business development which is hampered by the bureaucracy. This bureaucratic obstruction hinders the increase in capital for BUMDesa Padang Jaya and Desa Modang.

\section{REFERENCES}

1. Sumodiningrat, G. (1999). Kemiskinan: Teori, Fakta dan Kebijakan. Jakarta: Imfac.

2. Sumardjo. (2009). Manajemen Konflik, Kolaborasi dan Kemitraan. Pusat Kajian Resolusi Konflik dan Pemberdayaan (CARE IPB). Bogor: LPPM IPB.

3. Mardikanto, T., \& dan Soebiato, P. (2012). Pemberdayaan Masyarakat dalam Perspektif Kebijakan Publik. Bandung: Alfabeta.

4. Suharto, E. (2009). Membangun Masyarakat Memberdayakan Rakyat. Bandung: Refika ditama.

5. Sugiyono. (2010). Metode Penelitian Pendidikan Pendekatan Kuantitatif, kualitatif, dan R\&D. Bandung: Alfabeta. 